\title{
Streptococcus pneumoniae meningitis in an adult with normal cerebrospinal fluid
}

\author{
Emmanuel Montassier MD, David Trewick MD, Eric Batard MD PhD, Gilles Potel MD PhD
}

Competing interests: None declared.

This article has been peer reviewed.

Correspondence to: Dr. Emmanuel Montassier, emmanuelmontassier @hotmail.com

CMAJ 2011. DOI:10.1503 /cmaj.090310
1 60-year-old woman presented to our emergency department with a one-day history of fever and headache. Her medical history included an appendectomy and a hysterectomy. She was not taking any medications, and she had not recently taken any antibiotics. She had not she received a vaccination against pneumococcus.

The night before her visit to the hospital, the patient had a fever of $38.7^{\circ} \mathrm{C}$, a frontal headache and neck pain. She had no pain in her throat or ears. None of her family members or intimate contacts had a similar illness. When she presented to the emergency department, she was afebrile and her vital signs were stable. On examination, the patient had neck stiffness with no focal neurologic signs. She had a score of 15 on the Glasgow Coma Scale.

Laboratory investigations showed an elevated serum leukocyte count of 16.6 (normal 4-10) $\times$ $10^{6} / \mathrm{L}$. Her serum electrolyte and blood glucose levels were normal, as were her levels of liver enzymes. A blood culture and a lumbar puncture were done. The patient's cerebrospinal fluid was clear and colourless, and analysis showed a protein level of $0.39 \mathrm{~g} / \mathrm{L}$, a glucose level of $3.9 \mathrm{mmol} / \mathrm{L}$ (the serum glucose level was $6.1 \mathrm{mmol} / \mathrm{L}$ ) and a leukocyte count of less than $1 \times 10^{6} / \mathrm{L}$. A Gram stain of the patient's cerebrospinal fluid showed no organisms (Table 1). Because of the normal results of the lumbar puncture, the patient was sent home.

Three days later, the patient was contacted by a physician from the emergency department because

\section{- KEY POINTS}

- An early lumbar puncture may have a normal result in some patients with bacterial meningitis.

- A second lumbar puncture should be done if the patient has shown clinical symptoms of bacterial meningitis for fewer than 24 hours, if the patient's symptoms are worsening, or if the patient's blood culture is positive for an organism that causes bacterial meningitis.

- Blood culture is a valuable adjunct to lumbar puncture when bacterial meningitis is suspected. the initial blood culture was positive for Streptococcus pneumoniae. The patient returned to the hospital. She complained of neck stiffness and occasional shivering. On examination, she had persistent neck stiffness and no focal neurologic signs. Again, she had a score of 15 on the Glasgow Coma Scale. A second lumbar puncture showed clear, colourless cerebrospinal fluid with a protein level of $0.74 \mathrm{~g} / \mathrm{L}$, a glucose level of $3.8 \mathrm{mmol} / \mathrm{L}$ (the serum glucose level was $5.3 \mathrm{mmol} / \mathrm{L}$ ) and a leukocyte count of $63 \times 10^{6} / \mathrm{L}$. Again, no organisms were seen in a Gram stain of the cerebrospinal fluid (Table 1). A second blood culture was positive for S. pneumoniae. The first sample of cerebrospinal fluid had remained sterile, but S. pneumoniae was found in the sample obtained during the patient's second visit.

Bacterial meningitis was diagnosed with a four-day delay as of the initial clinical symptoms. The patient responded favourably to treatment with intravenous ceftriaxone.

\section{Discussion}

Most patients with bacterial meningitis (99\%) have a total leukocyte count of more than $100 \times 10^{6} / \mathrm{L}$ in their cerebrospinal fluid. ${ }^{1}$ For diagnosing bacterial meningitis, a glucose level in cerebrospinal fluid of less than $40 \%$ of the serum glucose level has a sensitivity of $80 \%$. Gram stain is positive in $60 \%-80 \%$ of patients with untreated bacterial meningitis. ${ }^{1}$

Bacterial meningitis with initially normal cerebrospinal fluid is uncommon among adults, but it is more likely to be seen among children. An initially normal sample may be the result of the lumbar puncture being done soon after the initial clinical symptoms begin, but other factors could also be involved, including intercurrent use of antibiotics (Table 2). ${ }^{1,2}$

For our patient, an initially normal result from a lumbar puncture was falsely reassuring and resulted in delayed treatment with antibiotics. Such a delay could have had a potentially fatal outcome. In a study involving 82 patients with 
documented meningitis, Coll and colleagues ${ }^{3}$ showed that eight $(9.7 \%)$ initially had normal cerebrospinal fluid. An early lumbar puncture had been done for each for these eight patients. At the time of the initial lumbar puncture, these eight patients had either had a cutaneous rash for $3.6 \pm 3.3$ hours or been febrile for $10.8 \pm 5.6 \mathrm{~h}$. In a small case series, Onorato and coauthors ${ }^{4}$ described five patients who had each had initially normal lumbar puncture results, but for whom a second lumbar puncture done 8-36 hours later showed bacterial meningitis.

Blood cultures are a valuable adjunct to cultures of the cerebrospinal fluid in patients with suspected meningitis. This strategy is recommended in the consensus guidelines of the Société de Pathologie Infectieuse de Langue Française (SPILF) ${ }^{1}$. Fuglsang-Damgaard and
Table 1: Results of two lumbar punctures from a 60-year-old woman who presented with fever and headache

\begin{tabular}{|lcc|}
\hline CSF values & Day 1 & Day 3 \\
\hline Glucose level, mmol/L & 3.9 & 3.8 \\
\hline Protein, $\mathrm{g} / \mathrm{L}$ & 0.39 & 0.74 \\
\hline Leukocyte count, $\times 10^{6} / \mathrm{L}$ & $<1.0$ & 63 \\
\hline $\begin{array}{l}\text { Ratio of CSF glucose level to } \\
\text { serum glucose level }\end{array}$ & 0.64 & 0.72 \\
Appearance & Crystal clear & Crystal clear \\
\hline Predominant cell type & Not reported & $\begin{array}{l}\text { Polymorphonuclear } \\
\text { leukocytes }\end{array}$ \\
\hline Gram stain & Negative & Negative \\
\hline Culture & Negative & Positive \\
\hline Note: CSF $=$ cerebrospinal fluid. & & \\
\hline
\end{tabular}

Table 2: Comparison between normal cerebrospinal fluid and the cerebrospinal fluid seen in meningitis with different causes, and the possible reasons for delays in diagnosis*

\begin{tabular}{|c|c|c|c|c|c|}
\hline Characteristic & Normal CSF & Bacterial meningitis & $\begin{array}{l}\text { Tuberculous } \\
\text { meningitis }\end{array}$ & $\begin{array}{l}\text { Listeria or fungal } \\
\text { meningitis } \\
\text { (cryptococcal) }\end{array}$ & $\begin{array}{l}\text { Viral meningitis, } \\
\text { rickettsial meningitis, } \\
\text { fungal meningitis } \\
\text { (cryptococcal), } \\
\text { leptospirosis, brucellosis } \\
\text { or syphilis }\end{array}$ \\
\hline Appearance & Crystal clear & Crystal clear or cloudy & Crystal clear & Crystal clear & Crystal clear \\
\hline $\begin{array}{l}\text { Leukocyte count, } \\
\times 10^{6} \text { cells } / \mathrm{L}\end{array}$ & $<10$ & $>10$ & $10-500$ & $>10$ & $>10$ \\
\hline Gram stain & Negative & $\begin{array}{l}\text { May be negative } \\
\text { (sensitivity is } 75 \% \text { in } \\
\text { Neisseria meningitis) }\end{array}$ & Rarely positive & $\begin{array}{l}\text { May be negative } \\
\text { (sensitivity in } \\
\text { Listeria meningitis: } \\
30 \% \text { ) }\end{array}$ & $\begin{array}{l}\text { Negative in viral } \\
\text { meningitis; may be } \\
\text { negative in the other } \\
\text { types }\end{array}$ \\
\hline Culture & Negative & May be negative & Positive in 3-6 wk & May be negative & May be negative \\
\hline $\begin{array}{l}\text { Reason for } \\
\text { possible delay in } \\
\text { diagnosis }\end{array}$ & & $\begin{array}{l}\text { CSF findings can be } \\
\text { normal in bacterial } \\
\text { meningitis if the lumbar } \\
\text { puncture is done early; } \\
\text { Gram stain and CSF } \\
\text { culture may be negative } \\
\text { in Neisseria meningitis; } \\
\text { Gram stain and culture } \\
\text { may be negative with } \\
\text { intercurrent use of } \\
\text { antibiotics in all forms of } \\
\text { bacterial meningitis }\end{array}$ & $\begin{array}{l}\text { Gram stain is } \\
\text { rarely positive; } \\
\text { culture could be } \\
\text { slow growing }\end{array}$ & $\begin{array}{l}\text { For Listeria } \\
\text { meningitis, Gram } \\
\text { stain and culture } \\
\text { may be negative } \\
\text { (especially with } \\
\text { intercurrent use of } \\
\text { antibiotics); CSF } \\
\text { leukocyte count } \\
\text { may be normal }\end{array}$ & $\begin{array}{l}\text { For Borrelia, Leptospira } \\
\text { and Brucella, Gram stain } \\
\text { and culture may be } \\
\text { negative (especially with } \\
\text { intercurrent use of } \\
\text { antibiotics) }\end{array}$ \\
\hline
\end{tabular}


coauthors $^{5}$ reported 20 instances of bacterial meningitis that were proven by blood culture when patients had normal initial lumbar punctures, resulting in delayed treatment with antibiotics. In that study, five patients died during their stay in hospital.

Our patient's experience highlights that results of tests on cerebrospinal fluid can be normal among adult patients with bacterial meningitis, especially when a lumbar puncture is done soon after the start of symptoms. In a patient with neck stiffness and fever, there should be a high degree of suspicion of meningitis, despite an early normal lumbar puncture result. Close follow-up is warranted. When a patient has shown clinical symptoms of bacterial meningitis for fewer than 24 hours, clinicians should consider a second lumbar puncture when the results of the initial lumbar puncture are normal. A second lumbar puncture should also be considered for patients whose clinical symptoms are worsening or if a blood culture shows positive results for an organism that is known to cause bacterial meningitis.

\section{References}

1. Stahl JP. 17ème conférence de consensus de la SPILF: prise en charge des méningites bactériennes aiguës communautaires (à l'exclusion du nouveau-né) [article in French]. Med Mal Infect 2009;39:145.

2. Association des Professeurs de Pathologie Infectieuse et Tropicale Méningites. 2nd edition. Montmorency (France): 2001. p. 253-262.

3. Coll MT, Uriz MS, Pineda V, et al. Meningococcal meningitis with 'normal' cerebrospinal fluid. J Infect 1994;29:289-94.

4. Onorato IM, Wormser GP, Nicholas P. Normal CSF in bacterial meningitis. JAMA 1980;244:1469-71.

5. Fuglsang-Damgaard D, Pedersen G, Schønheyder HC. Positive blood cultures and diagnosis of bacterial meningitis in cases with negative culture of cerebrospinal fluid. Scand J Infect Dis 2008;40:229-33.

Affiliations: From the Service d'accueil des urgences, Centre Hospitalier Universitaire de Nantes, Nantes, France

Contributors: Emmanuel Montassier and Eric Batard made substantial contributions to the conception and design of the article. David Trewick and Gilles Potel drafted the article. All of the authors revised the article for important intellectual content and approved the final version submitted for publication. 